\title{
FLEXURAL BEHAVIOUR OF REINFORCED CONCRETE SLABS USING STEEL SLAG AS COARSE AGGREGATE REPLACEMENT
}

\author{
P.Vasanthi ${ }^{1}$ \\ ${ }^{I}$ Asst.Professor, Department of Civil Engineering, Sathyabama University, Chennai, Tamilnadu, India
}

\begin{abstract}
The aim of this project is to test the strength and performance of concrete and flexural behaviour such as deflection and load acting on slabs of size 1400x1200x100mm, containing steel slag that is been used as partial replacement of natural coarse aggregate of size 20mm, as opposed to that of normal concrete. For this research work, M30 and M40 grade of concrete is used and test is conducted by casting slabs for various proportion of steel slag replacement of CA with 0\%, 30\%, 60\% and 100\%. The obtained results is been compared with both grade of concrete and it is been tabulated.
\end{abstract}

Keywords: Concrete, Steel Slag, Coarse aggregate

\section{INTRODUCTION}

Concrete is a widely used construction materials for various types of structures due to its durability. For a long time it was considered to be a very durable materials requiring little or no maintenance. Concrete is a composite construction material composed of cement (normal Portland cement), coarse aggregate (generally crushed stones or rock), fine aggregate (river sand), and water. Concrete hardness solidifies after mixing with water and placement due to a chemical process known as hydration. The water reacts with the cement which bonds the other components together, eventually creating a robust stone like materials. Concrete is used more than any other man - made materials in the world. So the use of concrete is unavoidable. At the same time scarcity of aggregates are also greatly increased nowadays.

The industrial waste has been encouraged in construction industries because it contributes to reduce the usage of natural resources. For many years, by product such as fly ash, silica fumes and steel slag were considered as waste materials. They have been successfully used in the construction industries, for the partial or full replacement of both fine and coarse aggregates.

Steel slag is widely used in construction industry and it has been used in manufacturing of road construction, pathway and pavements. It is a by - product of the manufacture of steel. To produce every tons of steel, approximately $3.0-$ 4.0 tons of steel slag is generated as a by - product materials. Since steel slag is glassy and granular and has similar particle size of both coarse aggregate (CA) and fine aggregate (FA), indicating that it can be used as a replacement of both coarse aggregate

\section{EXPERIMENTAL INVESTIGATION}

The main test variables for the present experimental investigation include cement type, w/c ratio and age of curing. The cement used in the investigation is ordinary Portland cement (OPC) of grade 43. OPC confirming to Indian Standards IS: 8112 - 1989. The specific gravity of OPC cement obtained is 3.15 . The coarse aggregate of size $20 \mathrm{~mm}$ and fine aggregate (River sand) are used in the proportion of $55 \%$ and $45 \%$ for M30 grade of concrete and $57 \%$ and $43 \%$ for M40 grade of concrete respectively by mass. The specific gravity of coarse aggregate $(20 \mathrm{~mm})$ is 2.82 and specific gravity for fine aggregate is 2.65 . The water absorption test for $20 \mathrm{~mm} \mathrm{CA}$ is $0.5 \%$ and for fine aggregate is $1.19 \%$ respectively.

The steel slag of size $20 \mathrm{~mm}$ that is been used as partial replacement with coarse aggregate of size $20 \mathrm{~mm}$ that is been obtained from M/S. Suryadev Power Plant. The specific gravity of steel slag used in this research work is 2.61 .

\subsection{Preliminary Tests Conducted}

\subsubsection{Sieve Analysis}

The sieve analysis of coarse aggregate was carried out as per the guidelines given in IS: $383-2008$. The sieves of different sizes were selected as per the guidelines specified in IS: $383-2008$.

Fineness Modulus $\quad 2.71$

\subsubsection{Specific Gravity}

1) Specific gravity of cement (OPC 43 grade ) $=3.15$

2) Specific gravity of fine aggregate $=2.65$

3) Specific gravity of coarse aggregate $(20 \mathrm{~mm})=2.82$

4) Specific gravity of steel slag $(20 \mathrm{~mm}) \quad=2.61$ 
Bulk Density $(\mathrm{k})=$ Mass / Volume.

a. Bulk density for coarse aggregate $=1680 \mathrm{Kg} / \mathrm{m}^{3}$

b. Bulk density for fine aggregate $=1770 \mathrm{Kg} / \mathrm{m}^{3}$

\subsection{Proportioning of Ingredients}

After getting the proportions of the mix, trial slump tests were carried out. Finally a water content of $185 \mathrm{Kg} / \mathrm{m}^{3}$ was selected for the water - cement ratio of 0.47 for M30 grade of concrete and 0.42 for M40 grade of concrete is used for all mixes.

\subsubsection{Mix - Design}

In this project Indian Standards Recommended guidelines is followed. The mix design for both M30 and M40 grade of concrete is shown in Table 2.1 and Table 2.2.

Table 2.1 Mix Design for M30 grade of concrete

\begin{tabular}{|c|c|c|c|c|c|c|c|}
\hline $\begin{array}{l}\text { Grade of } \\
\text { Concrete }\end{array}$ & $\begin{array}{l}\% \text { Of } \\
\text { Replacement } \\
\text { of Steel Slag }\end{array}$ & $\begin{array}{l}\text { W/c } \\
\text { Ratio }\end{array}$ & $\begin{array}{l}\text { Water } \\
\text { (lit) }\end{array}$ & $\begin{array}{l}\text { Cement } \\
\mathrm{Kg} / \mathrm{m}^{3}\end{array}$ & $\begin{array}{l}\text { Sand } \\
\mathrm{Kg} / \mathrm{m}^{3}\end{array}$ & $\begin{array}{l}\text { Coarse } \\
\text { Aggregate } \\
\mathrm{Kg} / \mathrm{m}^{3} \\
(20 \mathrm{~mm})\end{array}$ & $\begin{array}{l}\text { Steel slag } \\
\mathrm{Kg} / \mathrm{m}^{3} \\
(20 \mathrm{~mm})\end{array}$ \\
\hline \multirow{4}{*}{ M30 } & $0 \%$ & \multirow{4}{*}{0.47} & \multirow{4}{*}{185} & \multirow{4}{*}{360} & \multirow{4}{*}{844.164} & 1110.516 & 0 \\
\hline & $30 \%$ & & & & & 777.36 & 308.34 \\
\hline & $60 \%$ & & & & & 444.20 & 616.69 \\
\hline & $100 \%$ & & & & & 0 & 1027.81 \\
\hline
\end{tabular}

Mix Ratio =1:2.34:3.08

C.A: F.A $=55 \%: 45 \%$

Table 2.2 Mix Design for M40 grade of concrete

\begin{tabular}{|c|c|c|c|c|c|c|c|}
\hline $\begin{array}{l}\text { Grade of } \\
\text { Concrete }\end{array}$ & $\begin{array}{l}\% \text { Of } \\
\text { Replacement } \\
\text { of Steel Slag }\end{array}$ & $\begin{array}{l}\text { W/c } \\
\text { Ratio }\end{array}$ & $\begin{array}{l}\text { Water } \\
\text { (lit) }\end{array}$ & $\begin{array}{l}\text { Cement } \\
\mathrm{Kg} / \mathrm{m}^{3}\end{array}$ & $\begin{array}{l}\text { Sand } \\
\mathrm{Kg} / \mathrm{m}^{3}\end{array}$ & $\begin{array}{l}\text { Coarse } \\
\text { Aggregate } \\
\mathrm{Kg} / \mathrm{m}^{3} \\
(20 \mathrm{~mm})\end{array}$ & $\begin{array}{l}\text { Steel slag } \\
\mathrm{Kg} / \mathrm{m}^{3} \\
(20 \mathrm{~mm})\end{array}$ \\
\hline \multirow{4}{*}{ M40 } & $0 \%$ & \multirow{4}{*}{0.42} & \multirow{4}{*}{185} & \multirow{4}{*}{404} & \multirow{4}{*}{793.12} & 1131.60 & 0 \\
\hline & $30 \%$ & & & & & 792.12 & 314.20 \\
\hline & $60 \%$ & & & & & 452.64 & 628.40 \\
\hline & $100 \%$ & & & & & 0 & 1047.34 \\
\hline
\end{tabular}

Mix Ratio = 1:1.96:2.8

C.A: F.A $=57 \%: 43 \%$

\subsubsection{Flexural Test on Slab}

\section{Description}

The flexural test is conducted on slab member of size $1400 \times 1200 \times 100 \mathrm{~mm}$ which consist of steel slag that is been used as partial and full replacement with natural coarse aggregate of size $20 \mathrm{~mm}$. The main purpose of this test is to check the strength of the slabs (various percentage of replacement of steel slag such as $0 \%, 30 \%, 60 \%$ and $100 \%$ for coarse aggregate). The test is also mainly used to find the deflection of the member when the load is applied uniformly. Crack formation on slabs after testing under loading frame is shown in Fig 2.1.

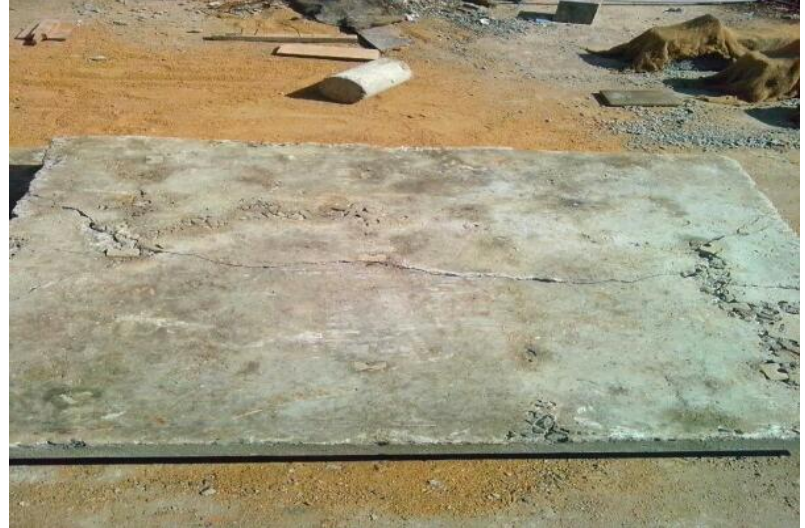

Fig: 2.1 Crack Pattern on slab after loading

\section{RESULTS AND DISCUSSION}

The results of different test such as N.D.T testing, Compression test for both 7 and 14 days, Flexural test on slabs for 14 days were carried out and tabulated as below. The graph is been plotted for required test results and comparison is been carried out for two different grade of concrete such as M30 and M40. 


\subsection{Slump Test}

Slump test was carried out for both grade of concrete M30 and M40 mixing for all the concrete mix. The slump values of OPC for all different mixes from $0 \%$ to $100 \%$ are calculated.

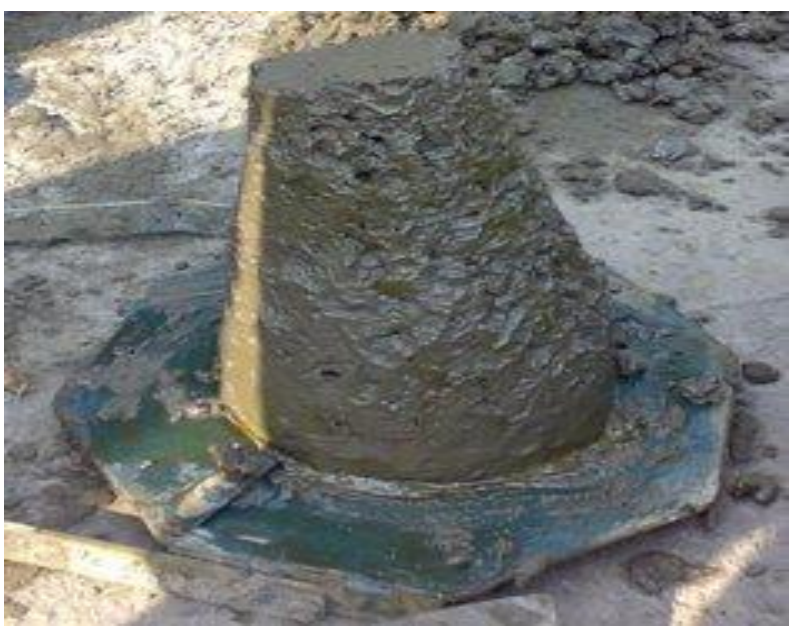

Fig: 3.1 Slump cone test

The mixes from SSA $0 \%$ to SSA $60 \%$ were found to be cohesive and showed no sign of bleeding and segregation. But SSA $100 \%$ shows sign of bleeding and segregation in both the grade of concrete. Hence it was rejected. So the fine was changed to $50 \%$ and a trial mix was made for SSA $100 \%$. This mix showed average workability. The slump of SSA $60 \%$ is shown in Fig 3.1.

\subsection{Non - Destructive Testing}

\subsubsection{Rebound Hammer}

Rebound hammer test was conducted for all the mixes for both 7 days and 14 days for M30 and M40 grade of concrete. Three set of trial was conducted for each mix in TNSCB. The values for each trial increases the percentage of steel slag $(0 \%, 30 \%, 60 \%, 100 \%)$

From the results we can see that the rebound number gradually increases as the percentage of steel slag is increased in each mix. But in the case of SSA $100 \%$ there is an appreciable decrease(0\%-47Mpa:100\%-40Mpa) in the value in both the grade of concrete M30 and M40, hence we can conclude that complete replacement of coarse aggregate with steel slag has reduced the surface hardness in concrete.

\subsubsection{Ultrasonic Pulse Velocity Test}

U.P.V test was conducted for all the mixes for both 7 days and 14 days for M30 and M40 grade of concrete. Three set of trial was conducted for each mix in TNSCB. From the results we can see that the quality of concrete is increasing as there is an increase in curing time i.e. for 7 days the quality of concrete is in medium range whereas for 14 days the quality of concrete comes under excellent and good range for both the grade of concrete.

\subsection{Compression Test}

To determine the compressive strength, eight cubes $(150 \mathrm{~mm}$ x $150 \mathrm{~mm} \times 150 \mathrm{~mm}$ ) were casted for each grade of concrete i.e. M30 and M40, for each mix and four samples were tested after 7 days and next four samples were tested after 14 days of curing. 7 and 14 days cube compressive strength test was conducted in accordance with IS: $516-1957$. All strength tests were carried out using $2000 \mathrm{KN}$ capacity compression testing machine in TNSCB.

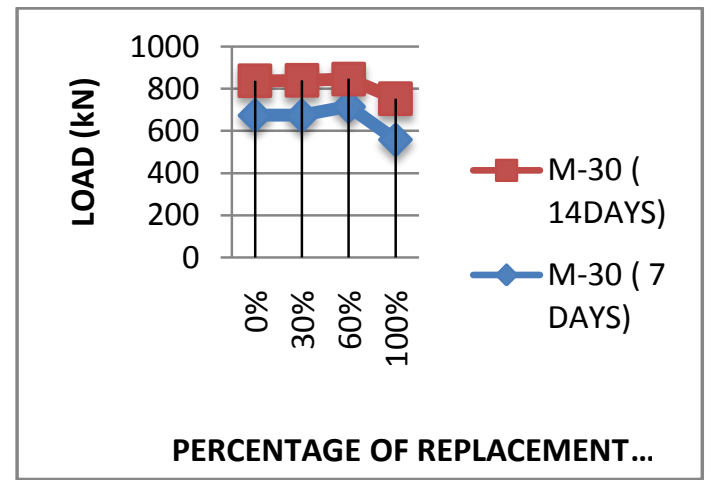

Fig.3.2 Compression strength graph for M30 grade of concrete

The compressive strength for M30 grade of concrete is shown in Fig 3.2 as above. As the curing days increases the strength also increases. It also shows that $60 \%$ of SSA attains max strength.

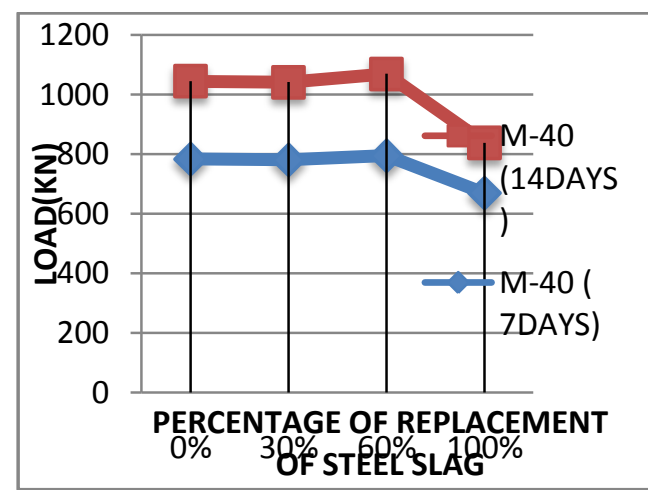

Fig: 3.3 Compression strength graph for M40grade of concrete

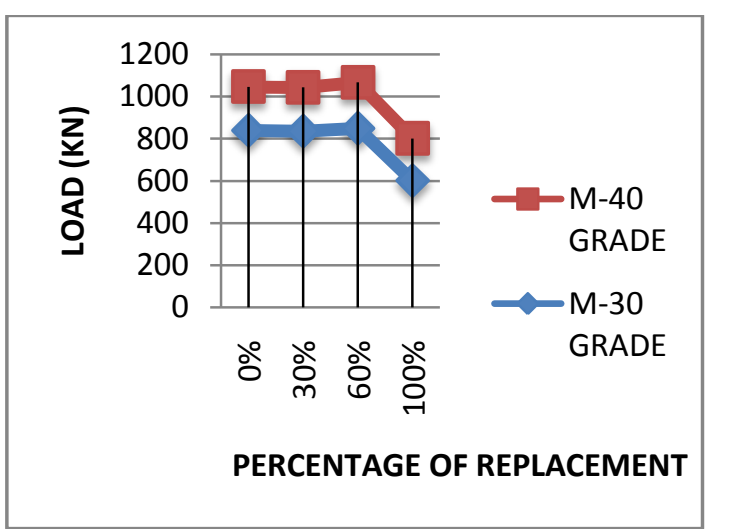

Fig: 3.4 Comparison of M30 and M40 grade of concrete compression strength 
The compressive strength graph for M40 grade of concrete is shown in Fig 3.3. As the curing days increases the strength also increases. It also shows that $60 \%$ of SSA attains max strength. From the comparison graph in Fig 3.4 shows that as the grade of concrete increases strength is also increasing.

\subsection{Flexural Test on Slabs}

To determine the flexural test, eight slabs $(1400 \mathrm{~mm} \mathrm{x}$ $1200 \mathrm{mmx} 100 \mathrm{~mm}$ ) were casted for both the grade of concrete i.e. M30 and M40, for each mix four slabs were tested on 14 days under the loading frame. The values is been tabulated as shown in Table 3.1 and Table 3.2 as below.

Table 3.1 Load - Deflection value of RCC slabs for M30 grade of concrete

\begin{tabular}{|c|c|c|c|c|c|c|}
\hline $\begin{array}{l}\text { Slab } \\
\text { Number }\end{array}$ & $\begin{array}{l}\% \text { Of } \\
\text { Replacement } \\
\text { (steel slag) }\end{array}$ & $\begin{array}{l}\text { Load } \\
(\mathrm{kN})\end{array}$ & $\begin{array}{l}\text { First } \\
\text { crack } \\
(\mathrm{kN})\end{array}$ & $\begin{array}{l}\text { D. G-1 } \\
\text { Reading }\end{array}$ & $\begin{array}{l}\text { D.G - } 2 \\
\text { Reading }\end{array}$ & $\begin{array}{l}\text { D.G - } 3 \\
\text { Reading }\end{array}$ \\
\hline 1 & $0 \%$ & $\begin{array}{l}10 \\
20 \\
30 \\
40\end{array}$ & 30 & $\begin{array}{l}0.93 \\
1.38 \\
1.68 \\
2.24\end{array}$ & $\begin{array}{l}1.01 \\
1.49 \\
1.75 \\
2.48\end{array}$ & $\begin{array}{l}0.96 \\
1.36 \\
1.72 \\
2.28\end{array}$ \\
\hline 2 & $30 \%$ & $\begin{array}{l}10 \\
20 \\
32 \\
40 \\
\end{array}$ & 32 & $\begin{array}{l}0.91 \\
1.40 \\
1.72 \\
2.16\end{array}$ & $\begin{array}{l}0.99 \\
1.44 \\
1.80 \\
2.21\end{array}$ & $\begin{array}{l}0.89 \\
1.42 \\
1.75 \\
2.18\end{array}$ \\
\hline 3 & $60 \%$ & $\begin{array}{l}10 \\
20 \\
30 \\
40\end{array}$ & 40 & $\begin{array}{l}0.78 \\
0.98 \\
1.48 \\
1.74\end{array}$ & $\begin{array}{l}0.84 \\
1.04 \\
1.53 \\
1.78\end{array}$ & $\begin{array}{l}0.82 \\
0.96 \\
1.46 \\
1.76\end{array}$ \\
\hline 4 & $100 \%$ & $\begin{array}{l}10 \\
20 \\
30 \\
40 \\
\end{array}$ & 20 & $\begin{array}{l}1.16 \\
1.68 \\
2.34 \\
4.52 \\
\end{array}$ & $\begin{array}{l}1.18 \\
1.76 \\
2.45 \\
4.58 \\
\end{array}$ & $\begin{array}{l}1.24 \\
1.74 \\
2.36 \\
4.58 \\
\end{array}$ \\
\hline
\end{tabular}

Table 3.2 Load - Deflection value of RCC slabs for M40grade of concrete

\begin{tabular}{|c|c|c|c|c|c|c|}
\hline $\begin{array}{l}\text { SLAB } \\
\text { NUMBER }\end{array}$ & $\begin{array}{l}\% \text { OF } \\
\text { REPLACEMEN } \\
\text { (STEEL SLAG) }\end{array}$ & $\begin{array}{l}\text { LOAD } \\
(\mathrm{KN})\end{array}$ & $\begin{array}{l}\text { FIRST } \\
\text { CRACK } \\
(\mathrm{KN})\end{array}$ & $\begin{array}{l}\text { D.G - } 1 \\
\text { READING }\end{array}$ & $\begin{array}{l}\text { D.G }-2 \\
\text { READING }\end{array}$ & $\begin{array}{l}\text { D.G - } 3 \\
\text { READING }\end{array}$ \\
\hline 1 & $0 \%$ & $\begin{array}{l}10 \\
20 \\
30 \\
40\end{array}$ & 40 & $\begin{array}{l}1.06 \\
1.41 \\
1.62 \\
2.14\end{array}$ & $\begin{array}{l}1.10 \\
1.46 \\
1.67 \\
2.28\end{array}$ & $\begin{array}{l}0.99 \\
1.45 \\
1.59 \\
2.19\end{array}$ \\
\hline 2 & $30 \%$ & $\begin{array}{l}10 \\
20 \\
32 \\
40\end{array}$ & 40 & $\begin{array}{l}0.87 \\
1.32 \\
1.71 \\
2.09\end{array}$ & $\begin{array}{l}0.94 \\
1.38 \\
1.74 \\
2.16\end{array}$ & $\begin{array}{l}0.92 \\
1.33 \\
1.78 \\
2.04\end{array}$ \\
\hline 3 & $60 \%$ & $\begin{array}{l}10 \\
20 \\
30 \\
40 \\
45\end{array}$ & $\begin{array}{l}\text { Till } 45 \mathrm{KN} \\
\text { No crack }\end{array}$ & $\begin{array}{l}0.90 \\
1.30 \\
1.48 \\
1.82 \\
2.00\end{array}$ & $\begin{array}{l}0.87 \\
1.31 \\
1.52 \\
1.86 \\
2.04\end{array}$ & $\begin{array}{l}0.92 \\
1.28 \\
1.54 \\
1.79 \\
1.98 \\
\end{array}$ \\
\hline
\end{tabular}

From the Table 3.1 and Table 3.2 shows that SSA $60 \%$ has very less deflection compared to other \% of SSA. It shows that as the strength of the member increases the deflection gets decreases. From the values obtained in the above tabulation shows that slab with $60 \%$ replacement of coarse aggregate with steel slag gives maximum strength. Whereas slab with $100 \%$ replacement does not attain much strength so there is a large deflection causing on the slab in both grade of concrete such as M30 and M40. But compare to M30 grade of concrete M40 attains much higher strength.

The load - deflection graph for M30 grade of concrete, replacement of coarse aggregate with SSA $0 \%$ is shown in Fig 3.5 as below. 


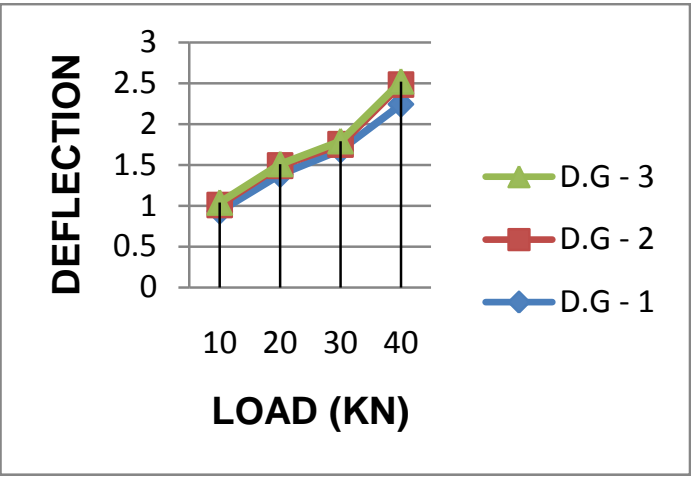

Fig: 3.5 Load - deflection graph for M30 grade (0\%)

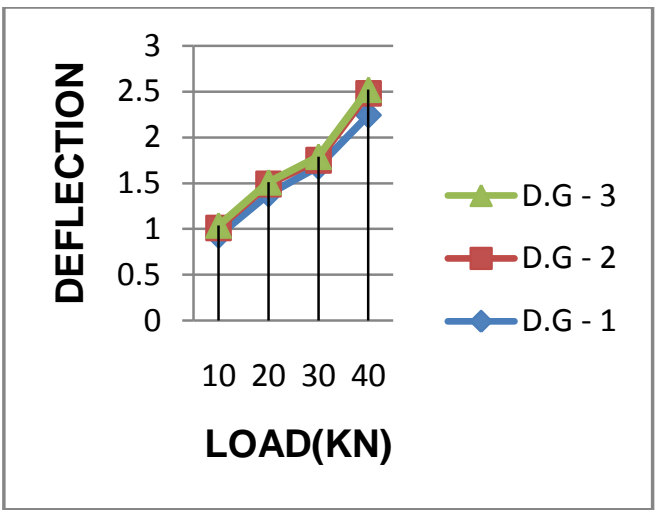

Fig: 3.6 Load - deflection graph for M30 grade (30\%)

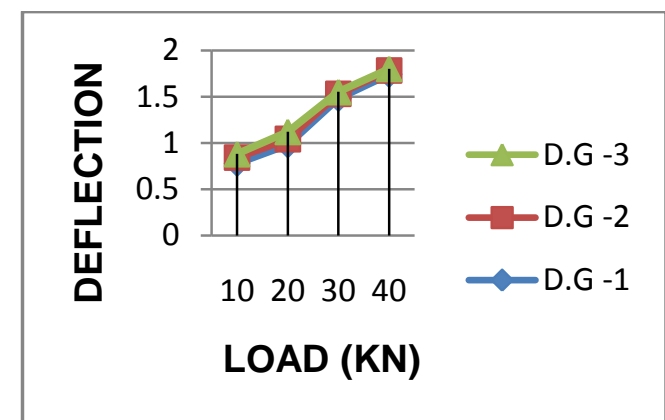

Fig: 3.7 Load - deflection graph for M30 grade (60\%)

The load - deflection graph for M30 grade of concrete replacement of coarse aggregate with SSA $30 \%$ and $60 \%$ is shown in Fig 3.6 and Fig 3.7 as above.

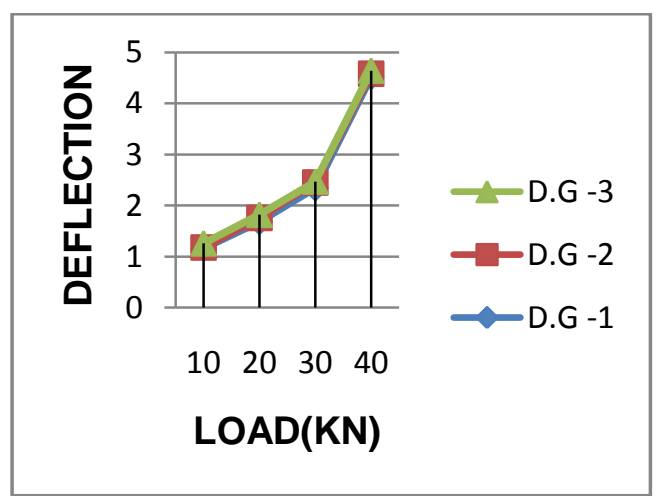

Fig: 3.8 Load - deflection graph for M30 grade (100\%)

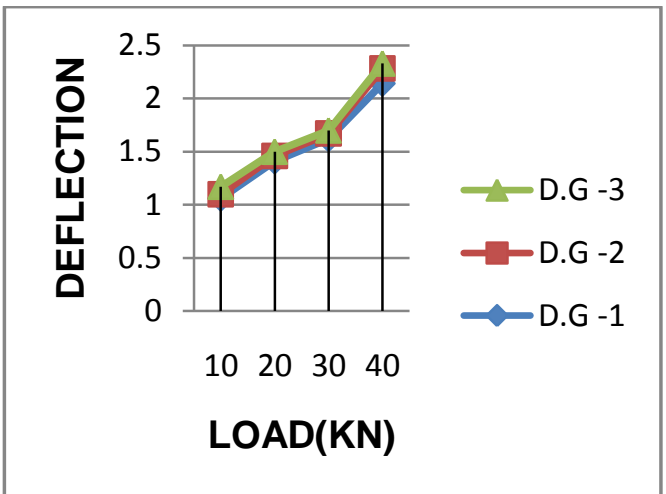

Fig: 3.9 Load - deflection graph for M40 grade (0\%)

The load - deflection graph for M30 grade of concrete replacement of coarse aggregate with SSA $100 \%$ shows that deflection is increasing due to decrease in strength and M40 grade of concrete replacement of coarse aggregate with SSA $0 \%$ is shown in Fig 3.8 and in Fig 3.9.

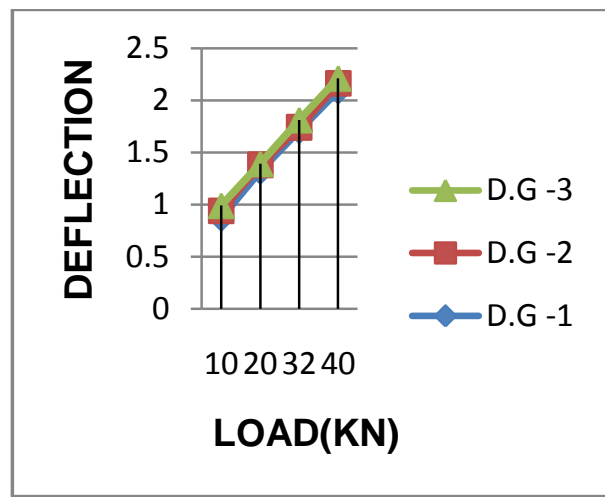

Fig: 3.10 Load - deflection graph for M40 grade (30\%)

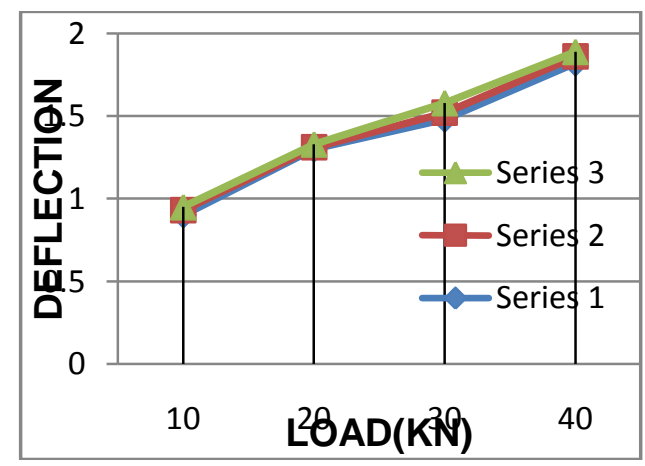

Fig: 3.11 Load - deflection graph for M40 grade (60\%)

The load - deflection graph for M40 grade of concrete replacement of coarse aggregate with SSA $30 \%$ and SSA $60 \%$ shows that there is reduction in deflection due to increase in strength is shown in Fig 3.6 and Fig 3.7 as above.

\section{CONCLUSIONS}

Steel - Slag which is a by - product of the manufacture of steel is one of the promising industrial by-products. It can be used in the construction industry as a partial substitute of either coarse aggregate or fine aggregate. This slag is currently being used in road construction work and also used 
in making path ways and pavements. These applications are utilizing only about 15 to 20 percent of the steel slag generated and the remaining materials is dumped as a waste, which requires large areas of land.

This project is to test the strength and performance of concrete and flexural behaviour such as deflection and load acting on slabs of size $1400 \times 1200 \times 100 \mathrm{~mm}$, containing steel slag that is been used as replacement of natural coarse aggregate of size $20 \mathrm{~mm}$, as opposed to that of normal concrete. For this research work, M30 and M40 grade of concrete is used and test is conducted by casting slabs for various proportion of steel slag replacement for CA with $0 \%, 30 \%, 60 \%$ and $100 \%$. There are totally 8 slabs, 4 slabs for M30 and 4 slabs for M40 grade of concrete each of weight $600 \mathrm{Kg}$. From the result obtained it shows that SSA $60 \%$ is the optimum replacement of coarse aggregate with steel slag and above SSA $60 \%$ the strength of slab is getting reduced in both M30 and M40 grade of concrete.

a. The use of steel slag as replacement of coarse aggregate in concrete is beneficial for the better workability and strength it imparts up to $60 \%$ replacement level.

b. It was also found that increase in replacement level of steel slag above $60 \%$ decreases the workability of concrete.

c. In comparing with M30 and M40 grade of concrete, M40 attains maximum strength compared to M30 grade of concrete.

d. This experimental study has proved to be better method or way in providing strong and durable concrete.

e. The highest compressive strength of $1065 \mathrm{kN}$ was obtained for SSA $60 \%$ for M40 grade of concrete. The corresponding strength of $847 \mathrm{kN}$ was obtained for SSA $60 \%$ for M30 grade of concrete.

f. With higher level of replacement of CA with SSA $100 \%$ there was a slight bleeding and segregation tendency. Therefore, it is recommended that up to SSA $60 \%$ can be used as replacement of coarse aggregate.

g. The experience in the present study indicates that up to $60 \%$ of coarse aggregate can be made up of steel slag and the rest can be made up normal natural coarse aggregate. However the actual content of steel slag depends upon the grade of concrete and bonding of aggregate available for use of concrete.

\section{REFERENCES}

[1] Akihiko Y, Takashi Y. Study of utilization of steel slag as coarse aggregate for concrete. Akshikaya Kogyo Daigaku Kenkyu Shuroku 1996:23:79 / 85.

[2] Alnuaimi S (2005) "Use of steel slag as a replacement for coarse aggregate in reinforced concrete slender columns", the WIT e Lib, Paper ID $=20138$

[3] Bipragorai, R.K. Jana, Premchand, "Characteristics and utilization of steel slag a review". Resources, Conservation and Recycling 39 (2003) pp 299 313.
[4] Caijun Shi, Christain Meyer, Ali Behnood, "Utilization of steel slag in cement concrete" Resources Conservation and Recycling 52 (2008) pp 1115 - 1120.

[5] Caijun Shi, Jueshi Qian "High performance cementing material from industrial slags. Resources Conservation and Recycling 29 (2000) pp 195 207.

[6] F. Li (1999), "Test research on steel slag concrete", Natural science edition, J Fuzhou University 127(5), pp $59-62$.

[7] Hwang CL, Laiw JC. (1989) "Properties of concrete using steel slag as a substitute for fine aggregate", the $3^{\text {rd }}$ international conference, SP11482, pp 1677 95.

[8] L.Zong (2003), "The replacement of granulated steel slag for coarse aggregate replacement in concrete", J Qingdao Inst Architect Eng 24 (2) pp 20 - 22.

[9] Teik Thye Lim, J. Chu, "Assessment of the use of spent steel slag for land reclamation". Waste Manage Res 2006: 24: pp 67 - 73.

[10] Washington Almeida Moura Jardel Pereira Gonc, Alves Monica batista Leite Lima, "Steel slag waste as a supplementary CA material to concrete" J Mater Sci (2007) 42: pp 2226 - 2230. 